\title{
LEADING A CONSTITUTIONAL COURT: PERSPECTIVES FROM THE FEDERAL REPUBLIC OF GERMANY
}

\author{
PETER E. QUINT ${ }^{\dagger}$ \\ INTRODUCTION
}

In order to make sense of any sort of comparison, there must ordinarily be some degree of similarity among the things that are to be compared. In comparative constitutional law, for example, it seems clear that a basic similarity in underlying principles-a common acceptance of what German constitutional law calls the "free democratic basic order"-is a fundamental presupposition of most contemporary endeavors in the area.

Yet it is not the similarities, but rather the differences, that lend these endeavors their special piquancy and much of their value. More specifically, it is the myriad differences, set out against the background of common agreement, that often make these comparisons worthwhile-because the differences represent alternative means that have been chosen in various systems to pursue what is essentially a common end. In any event, the differences are ubiquitous: the more deeply one probes into an issue in comparative constitutional law, the more evident it becomes that almost nothing is precisely the same in any two legal systems.

Certainly a comparison of the respective roles of the Chief Justice of the United States and the President of the Federal Constitutional Court of Germany requires us to consider two systems whose underlying presuppositions are in many ways quite similar. In general principle, moreover, the functions of the official leaders of these two eminent tribunals are also in many respects the same.

But that is indeed where the similarities end-in general principles. When we examine the actual institutions themselves-the Supreme Court of the United States and the Constitutional Court of the Federal Republic of Germany-we see that, in many aspects of ex-

${ }^{\dagger}$ Jacob A. France Professor of Constitutional Law, University of Maryland School of Law. I am grateful to Russell Miller for valuable comments on an earlier draft of this Essay. All translations in this Essay are by the author. 
tremely important detail, there are very wide differences between the institutional structures and functions of these two important constitutional courts. Moreover, as the institutional aspects of these two courts differ, these differences result in quite substantial variations between the roles of the two chief judicial officers: the Chief Justice of the United States and the President of the German Constitutional Court.

But it is also clear that no constitutional or statutory drafter ever focused in the first instance on the design of the chief judicial officers of these two constitutional courts. Rather, the principal focus was on the design of the respective tribunals as institutions, and, in many respects, the salient characteristics and relative power of the chief judicial officers have followed rather logically from differences in the basic design of the two institutions.

It is, of course, not the place here to engage in an extended disquisition on the Constitutional Court of the Federal Republic of Germany-although many readers may not be immediately familiar with this institution. Suffice it to say that the Constitutional Court was established after World War II to interpret and enforce the Basic Law (constitution) of the Federal Republic of Germany and that, in the more than five decades of its existence, the Court has developed an extensive constitutional jurisprudence of considerable subtlety and power. ${ }^{1}$ While most of the Court's decisions are handed down in procedures that-roughly speaking-resemble the concrete "cases" and "controversies" of American constitutional law, the Court's jurisdiction also includes certain "abstract" proceedings initiated by a state or by one-third of the members of parliament, or by one "constitutional organ" claiming that another "organ" has invaded its sphere of competence. $^{2}$ A number of other differences between the two courtsspecifically relevant to our topic-will be touched upon in the paragraphs below.

So let us begin with the differences between the Chief Justice of the United States and the President of the German Constitutional Court-differences that grow out of variations in the respective judicial institutions themselves. As we proceed with this examination, a

\footnotetext{
${ }^{1}$ For comprehensive works in English on the jurisprudence of the German Constitutional Court, see DONALD P. KOMMERS, THE CONSTITUTIONAL JURISPRUDENCE OF THE FEDERAL REPUblic OF GERMANY (2d ed. 1997); DAVID P. CURRIE, THE CONSTITUTION OF THE FEDERAL REPUBLIC OF GERMANY (1994).

${ }^{2}$ Grundgesetz [GG] [Constitution] art. 93, §1, cls. 1-2, available at http:// dejure.org/gesetze/GG (last visited Apr. 20, 2006).
} 
number of important similarities between the two offices will also become apparent.

\section{TWO SEPARATE PANELS}

In a number of significant instances, the institutional structure of the German Constitutional Court seems to accord the Court's President distinctly less power than that exercised by the Chief Justice of the United States. One crucial difference, for example, is that the Constitutional Court of the Federal Republic of Germany is actually more like two courts than one-in sharp contrast with the Supreme Court of the United States which, according to the constitutional text, must consist of "one Supreme Court."

As part of a political compromise entered into when the German Constitutional Court was established in 1951, parliament decided that the Court should be divided into two separate panels or "Senates." At the outset, each panel consisted of twelve justices, but since 1962 that number has been set at eight justices for each Senate. ${ }^{4}$

The work of the Court is divided between the two Senates according to the subject matter of the particular case. Thus, with some significant exceptions, matters of individual rights come before the socalled "First Senate," and matters of governmental structure are decided by the "Second Senate." Upon appointment, each justice is assigned to one of the two Senates and may not ordinarily participate in the work of the other Senate. Although the two Senates are authorized to sit together in certain circumstances (in a body called the Plenum $),{ }^{6}$ this joint meeting does not take place very frequently. The re-

${ }^{3}$ U.S. CONST. art. III, $\$ 1$.

${ }^{4}$ The German Basic Law does not actually require that the Constitutional Court be divided into two Senates. Like the Constitution of the United States, the Basic Law provides only a few guidelines for the structure and nature of its highest constitutional tribunal. As a result, most decisions concerning the Court's size, structure, and operation were left to legislative decision. See GG arts. 93-94. Thus, as the Judiciary Act of 1789 filled in many of the details relating to the Supreme Court of the United States, the so-called "Constitutional Court Act" of 1951 (as amended) provides most of the details concerning the characteristics of the German Constitutional Court. See Gesetz über das Bundesverfassungsgericht [BVerfGG] [Federal Constitutional Court Act], Aug. 11, 1993, BGBl. I at 1473, last amended on Dec. 15, 2004, BGBl. I at 3396, 3403; DONALD P. KOMMERS, JUdiCial POLITICS IN WEST GERMANY 86-87 (1976); UWE Wesel, DER GANG NACH KARLSRUHE 38-42 (2004).

${ }^{5}$ In order to equalize the workload, a limited number of individual rights issues have been shifted into the jurisdiction of the Second Senate.

${ }^{6}$ See, e.g., BVerfGG $\S 16$ (conferring jurisdiction on the Plenum to resolve inconsistencies between constitutional views of the two Senates). 
sult is, therefore, that the two Senates of the Constitutional Court in effect constitute two different courts. ${ }^{7}$

The President of the Constitutional Court is the presiding officer of only one of the two Senates: the presiding officer of the other Senate is an entirely different judge, who is called the Vice President of the Court. (Of the eight Presidents of the German Constitutional Court from 1951 to the present, six have been the presiding officer of the First Senate, and two have been the presiding officer of the Second Senate. $)^{8}$ As a result, any possible special influence that the President might wield-as President-in the conferences and certain other inner workings of the Court, relating to the actual decision of cases, is likely to be restricted to one Senate alone. The Vice President may have this power-or something like it-in the other Senate. Therefore, one could argue that there are two "Presidents" of the Constitutional Court, although I think it is fair to say that the actual "President" does wield a degree of unique moral and practical authority, as will be discussed further below.

\section{TWELVE-YEAR NONRENEWABLE TERMS}

Another difference of considerable importance-which also may diminish the comparative authority of the President of the German Court-arises from differing rules relating to the tenure of office of the judges. While the Justices of the American Supreme Court, including the Chief Justice, are in effect chosen for life, the judges of the German Constitutional Court (including the President and Vice President) are appointed for nonrenewable twelve-year terms. ${ }^{9}$ This

\footnotetext{
${ }^{7}$ KOMMERS, JUdicial POLITICS, supra note 4, at 86.

${ }^{8}$ See Verfassungsrechtsprechung 665-75 (Jörg Menzel ed., 2000) (listing the judges of the Constitutional Court).

${ }^{9}$ BVerfGG $\S 4(1)$. This rule, which is of statutory rather than constitutional origin, has been in effect since 1970. At an earlier period, some judges enjoyed unlimited terms (up to the mandatory retirement age), while other judges were appointed to $r e-$ newable eight-year terms. KOMMERS, JUDICIAL POLITICS, supra note 4, at 88.

The judges of the Constitutional Court are chosen in the following manner: half of the judges are elected by the Bundesrat (the upper house of the German parliament, which represents the states), and half of the judges are chosen by a committee of the Bundestag (the popular house of parliament). BVerfGG $\$ \S 5-6$. In each case, a two-thirds vote is necessary in order to select a Constitutional Court judge. Id. $\$ \S 6(5)$, 7. This rule, which effectively eliminates the possibility that a single political party may dictate the appointment, tends to favor judges from the center of the ideological spectrum. The Bundesrat and the Bundestag committee alternate in the choice of the Court's President and Vice President. Id. $\$ 9(1)$. Three judges of each Senate of the Constitutional Court must be drawn from the highest courts of the "ordinary" judici-
} 
choice represents an alternative method of achieving judicial independence: even though the Constitutional Court judges have limited terms, they cannot be reappointed and therefore-the theory goesthey would be unlikely to trim their decisions to achieve any sort of political favor with executive or legislative officials. ${ }^{10}$

The result of these shorter judicial terms is that there is a reduced chance for the exercise of influence by the Constitutional Court President over a very long period of time. One could compare, for example, the shorter German terms with the recent example of William Rehnquist, who served for nineteen years as Chief Justice (after fourteen years as Associate Justice). Indeed, during the period from 1951 (when the Constitutional Court was established) until the present, there have been eight Presidents of the Constitutional Court, whereas-during the same period-there have only been five Chief Justices of the United States (actually, only four, if one excludes the tenure of newly appointed Chief Justice Roberts). ${ }^{11}$ Indeed, even more extreme disparities are readily imaginable: the period from 1801 to 1864 , for example, encompassed the chief justiceships of only two individuals, Marshall and Taney. But this period is considerably longer than the period from 1951 to the present, which covers the entire history of the German Constitutional Court and includes therefore the entire tenure of its eight Presidents.

Thus, the limitation on terms of office furnishes another way in which the authority of the President of the Constitutional Court may

ary. Id. $\S 2(3)$; see infra note 35 and accompanying text (reviewing the basic structure of the "ordinary" legal system). In practice, the justices are actually chosen by secret agreement among the political parties, and there are no public hearings on the judges' qualifications, such as those that have become common for Supreme Court nominees in the United States. For a discussion of proposals to limit American Supreme Court Justices to a single nonrenewable term, see Stephen B. Burbank, Alternative Career Resolution II: Changing the Tenure of Supreme Court Justices, 154 U. PA. L. REV. 1511 (2006).

${ }^{10}$ In 1994, Roman Herzog, at the time President of the Constitutional Court, was nominated by the conservative coalition for the (largely ceremonial, but very eminent) office of President of the German Federal Republic. WERnER FILMER \& HERIBERT SCHWAN, ROMAN HERZOG: Die BIOGRAPHIE 223 (1996). Thus, the eligibility of a Constitutional Court judge for an eminent high office, before or after the expiration of his or her twelve-year term, might theoretically raise an issue of compromised independence. Of course, the same possibility arises in the United States also, as a Justice of the Supreme Court might resign to accept another governmental position, as occurred, for example, in the cases of Justices James Byrnes and Arthur Goldberg.

${ }^{11}$ The American Chief Justices during this period are: Vinson, Warren, Burger, Rehnquist, and Roberts. 
seem limited, to some extent, in comparison with that of the Chief Justice of the United States. ${ }^{12}$

\section{LIMITED AUTHORITY OVER ASSIGNMENT OF OPINIONS}

The Chief Justice of the United States has only one vote in the Court's conference-as does each of the other Justices. It is often said, therefore, that much of the special power of the Chief Justice's role lies in his authority over the assignment of opinions written for the Court. The Chief Justice assigns all opinions in cases in which he votes with the majority; the senior Justice in the majority assumes that function if the Chief Justice dissents from the decision. ${ }^{13}$ It is sometimes said that a Chief Justice has employed this authority to help cement coalitions, to improve his tactical position with various members of the Court, and to direct opinions in important cases toward those Justices whose views are most like his own. It has also been said that, from time to time, a Chief Justice may even forego casting a dissenting vote and switch to the majority side (perhaps only temporarily), in order to be able to assign the opinion in an important case. ${ }^{14}$

Whatever power an American Chief Justice may exercise through this authority (and these possible maneuvers), any parallel authority is greatly reduced in the case of the President of the Constitutional Court of the Federal Republic of Germany. First, of course, the President of the Constitutional Court could possess such possible authority

\footnotetext{
${ }^{12}$ Moreover, in a reflection, perhaps, of the bureaucratic nature of the German judiciary, the judges of the Constitutional Court (including the President and Vice President) are required to retire upon reaching the age of sixty-eight. BVerfGG $\S$ 4(3). Thus, a Constitutional Court President who is over the age of fifty-six when he or she is appointed will ordinarily not even be allowed to serve a full period of twelve years. Accordingly, President Jutta Limbach, who was sixty years old when she ascended to the Court, was permitted to serve for eight years only. KARIN DECKENBACH, JUtTA LimbaCH: EINE BiogRAFIE 173, 223 (2003); Donald P. Kommers, Jutta Limbach, in WOMEN IN LAW: A Bio-Bibliographical Sourcebook 144, 149 n.1 (Rebecca Mae Salokar \& Mary L. Volcansek eds., 1996).

On the other hand, a Constitutional Court judge whose term has expired continues in office until his or her successor has been officially chosen. BVerfGG $\$ 4(4)$; Klaus SCHLAich \& STEFAN Korioth, DAS Bundesverfassungsgericht 32 (6th ed. 2004). Thus the formula recently invoked by retiring Justice Sandra Day O'Connor in the United States has long been enshrined in German statutory law. In the case of a stalemate over the choice of a successor, a judge's term might therefore be perceptibly extended.

${ }^{13}$ For a history of this practice, see G. Edward White, The Internal Powers of the Chief Justice: The Nineteenth-Century Legacy, 154 U. PA. L. REV. 1463, 1476-84 (2006).

${ }^{14}$ For a discussion of voting strategy on the Court, see Paul J. Wahlbeck, Strategy and Constraints on Supreme Court Opinion Assignment, 154 U. PA. L. REV. 1729 (2006).
} 
with respect to only one of the two Senates-the Vice President would have parallel authority in the other Senate. But more important, neither the President nor the Vice President actually possesses the discretionary authority to assign opinions of the Court in most instanceseven in his or her own Senate. Finally, the fact that majority opinions in the Constitutional Court are unsigned, along with other differences, may affect the dynamics (and politics) of opinion writing in significant ways.

To understand the full force of these points, it will be necessary to step back for a moment and consider the nature of judicial opinions in the Federal Constitutional Court from a more general perspective-because the differences from opinions in the Supreme Court are significant. The first important point of difference is that in Germany, as in most continental countries, an appellate panel's opinion is not signed by its individual author. Moreover, in all German courts (with the exception of the Constitutional Court), all separate opinionsthat is, concurring or dissenting opinions-are prohibited. ${ }^{15}$ Thus in almost all German courts the panel speaks with an impressive unanimity, even though the participating judges may have been deeply and bitterly split on a particular issue.

Until 1970, this rule of forced unanimity prevailed in the Constitutional Court as well. Apparently some members of parliament had wished to authorize separate opinions when the Constitutional Court was established in 1951, but the majority was unwilling to allow this innovation in the German legal system. In the 1960s, however, certain opinions of the Court began to reveal that there actually were divisions on the panel-by indicating the numbers and views of the opposing justices, although not disclosing their names. ${ }^{16}$ In response to this not so subtle judicial pressure, the parliament enacted a statute in 1970 allowing "deviating" (abweichende) opinions, which were to be signed by the author. ${ }^{17}$ This liberalizing amendment applied to the Federal Constitutional Court alone.

But even after the introduction of signed dissents and concurrences in 1970, the majority opinions of the German Constitutional Court (whether or not they are accompanied by separate opinions) remain unsigned. Yet, of course, there is a principal author of each

\footnotetext{
${ }^{15}$ SCHLAICH \& KORIOTH, supra note 12 , at 39.

${ }^{16}$ For a well-known example of such an opinion, see Bundesverfassungsgericht [BVerfG] [Federal Constitutional Court] Aug. 5, 1966, 20 Entscheidungen des Bundesverfassungsgerichts [BVerfGE] 162 (F.R.G.) (Spiegel Case).

${ }^{17}$ BVerfGG $\$ 30$ (2); SCHLAICH \& KORIOTH, supra note 12 , at 38-42.
} 
opinion. That author is not ordinarily chosen, however, at the discretion of the President (or Vice President) of the Constitutional Court. Rather, the author is ordinarily chosen according to the subject matter of the constitutional case to be decided.

The system works in the following manner: the jurisdiction of each of the two Senates is divided into broad general subject matter areas-such as freedom of expression, freedom of religion, eminent domain, etc. (in the First Senate), and issues relating to the European Union, international law, the rights and structure of parliament, etc. (in the Second Senate). Then the subject matter areas of each Senate are allocated in an equitable manner among the justices of the Senate. ${ }^{18}$ When a new justice comes to the Constitutional Court, he or she will ordinarily assume responsibility for certain subject matter areas that are open at the time. Thus, each justice becomes an expert in specific subject matter areas within the jurisdiction of his or her Senate. ${ }^{19}$ The result is, however, that when a particular case comes to the Court, it is assigned to the justice who maintains responsibility for the constitutional area into which the case falls.

On the other hand, there may be some overlapping of assigned areas. Moreover, some of the cases may not fall into any of the areas that have been specified-although even under these circumstances, the "division of business" document may set forth detailed guidelines for the assignment of the relevant cases. Yet in some of these procedural gray areas, the President in his or her Senate (and the Vice President in the other Senate) may possibly retain some independent discretion. $^{20}$

The justice who receives the assignment of a case-usually because the case falls within his or her area of expertise-is known as the "Reporter" (Berichterstatter). The main task of the Reporter is to write a long memorandum on the case, called a "votum," which ordinarily

${ }^{18}$ This "division of the business of the Court" (Geschäftsverteilung) is set out in great detail and published each year as an official document of the Court. The Geschäftsverteilung document for each of the last seven years may be found at the Court's website: http://www.bundesverfassungsgericht.de/organisation.html (last visited Apr. 20, 2006) [hereinafter Geschäftsverteilung documents, 2000-2006].

${ }^{19}$ Apparently, it is possible for justices to trade subject matter areas among themselves. For an example, see Reinhard Müller, Di Fabio auf Kirchhofs Spuren, FrANKFURTER AllgEMEINE ZEITUNG, Aug. 16, 2005, at 4.

${ }^{20}$ Geschäftsordnung des Bundesverfassungsgerichts [Rules of the Federal Constitutional Court], Dec. 15, 1986, BGBl. I at 2532, § 20(2) (F.R.G.). Moreover, if the Senate agrees, the President (or Vice President) may choose an additional justice to share the task of writing the opinion in particularly important cases. Id.; ERNST BENDA \& ECKART KLEIN, VERFASSUNGSPROZESSRECHT 65 (2d ed. 2001). 
becomes the basis for the Court's opinion in that case. When the case is debated in conference, however, a majority of the justices may make any changes they choose in the opinion derived from the votum, and neither the author of the votum nor the President has any formal influence over these changes. Of course, a particular justice may exert significant influence on the conference by virtue of personal powers and abilities, and that may well include the special expertise possessed by the Reporter. Indeed, this special expertise may often give the Reporter extraordinary authority over the opinion and resultparticularly in complex cases in which a deep knowledge of the subject matter by the Reporter gives him or her a decided advantage. ${ }^{21}$

Yet even in this system, which seems to deprive the President of the Constitutional Court of the influence resulting from the independent assignment of opinions, the system may nonetheless accord a degree of special-although informal-authority to the President. In the period before 1970, when justices were not permitted to ventilate their independent views by writing a separate dissenting or concurring opinion, there apparently was substantial pressure within the internal dynamics of the Court to reach some sort of decision that was agreeable to all. Under these circumstances, a President of the Court who had talents as a mediator was able to exercise a special degree of authority within his or her own Senate. The first President of the Constitutional Court, Hermann Höpker-Aschoff, although not an impressive legal technician, seemed to possess a "genius" for such mediating efforts, and his presidential role in directing the conferences of the justices gave him scope for the exercise of this influence within his own Senate. $^{22}$ Even now, when dissenting and concurring opinions are possible, they are actually written much less frequently in the German Constitutional Court than they are in the Supreme Court of the United States, and the pressures for a large number of unanimous opinions may still be strong. Thus, it may be that a President (or Vice

${ }^{21}$ It is often said, for example, that Professor Paul Kirchhof of Heidelberg, who was a judge of the Second Senate from 1987 to 1999, was able to insert several of his own distinctive constitutional and economic theories into the Court's opinions in tax cases, as well as in the Court's important decision on the European Union's Maastricht Treaty. WESEL, supra note 4, at 297-302, 362-65. Kirchhof was the Reporter in these cases, and his influence seemed particularly strong in his areas of expertise.

${ }^{22}$ Kommers, JUdicial POLitics, supra note 4, at 188-89. In the United States, Chief Justice Marshall appears to have been able to exercise a similar unifying influence, particularly in the earlier years of his tenure when most decisions were unanimous and were announced in opinions written by the Chief Justice himself. Charles F. Hobson, Defining the Office: John Marshall as Chief Justice, 154 U. PA. L. REV. 1421, 1426$31(2006)$ 
President) of the Constitutional Court, with exceptional talents for mediation, may continue to play an especially influential role in the councils of his or her particular Senate.

\section{THE COURT'S SCREENING COMMITTEES}

The role of the President of the Constitutional Court is also affected-and in this case perhaps somewhat enhanced-by an important difference in the procedure of decisionmaking in the Constitutional Court, in contrast with that of the Supreme Court of the United States. This difference concerns the process of screening cases in the Constitutional Court.

Each year litigants file more than five thousand Constitutional Complaints asking the Court to invalidate a wide variety of governmental actions. ${ }^{23}$ Of course, only a very small fraction of these Complaints can be decided in full Senate opinions. Yet the Court's procedure still reflects the strongly held and perhaps quixotic view-dating back to the era of the Court's origins-that every person filing a Constitutional Complaint is, in principle, entitled to a decision on the merits. Such a commitment has made it impossible, up until now, for the Court to adopt a discretionary review system such as the certiorari jurisdiction of the Supreme Court of the United States.

As a result, the overwhelming majority of decisions of the Constitutional Court are not rendered by a full Senate, but rather by threejudge committees (Kammern) whose task is to screen and decide most of these Constitutional Complaints. ${ }^{24}$ These screening committees function in the following manner: if a committee finds that a Constitutional Complaint is clearly without merit-or if it is otherwise unacceptable on certain other grounds-the committee dismisses the Complaint. If, in contrast, the committee finds that the Complaint is clearly meritorious, it may issue a decision in favor of the complainant. In both kinds of cases, the committee's decision must be unanimous, and it is unreviewable.

The opinions written by the committees may be summary in nature, but they can also be long and complex under some circumstances. These committee decisions are obviously less authoritative than full Senate decisions, and they are ordinarily not included in the official reports of the Constitutional Court. In important instances,

\footnotetext{
${ }^{23}$ SCHLAICH \& KORIOTH, supra note 12, at 59.

${ }^{24} I d$. at 58-59.
} 
however, these opinions are reprinted (in edited form) in German law journals. ${ }^{25}$ It is only if a Constitutional Complaint falls in the gray area between a clearly non-meritorious and a clearly meritorious claim that the screening committee sends the Complaint to the full Senate for additional screening and possible decision.

Thus, the screening committees of the German Constitutional Court play a subsidiary, but nonetheless important, role in the development of the jurisprudence of the Constitutional Court. They indeed can play a substantive role in the development of doctrineunlike the certiorari procedure, which serves the function of screening cases in the Supreme Court of the United States.

There are usually three of these three-judge screening committees in each of the two Senates of the Constitutional Court. "As there are only eight judges on each Senate, it is clear that one judge in each Senate must serve on two screening committees." ${ }^{26}$ Invariably in recent years the President has served on two of the screening committees in his or her Senate. ${ }^{27}$ To this extent, then, the process of screening gives an additional vote in these committees to the President of the Court, and therefore-to some perhaps unknowable degree-may accord the President somewhat more influence in the decision of a large number of Constitutional Complaints on this secondary level of the Court's adjudication.

On the other hand, in light of this increased committee work as well as other important administrative duties, the President ends up writing significantly fewer opinions as Reporter for the full Senate than the average number written by the other judges. ${ }^{28}$ So to the extent that the Reporter has special influence over the decisions of the full Senate, it could be the case that, in this respect, the President's influence is somewhat diminished.

${ }^{25}$ In addition, the initial volumes of a new series of reporters, reprinting selected opinions of the screening committees, have recently appeared. 1-6 BVERFGK, KAMMERENTSCHEIDUNGEN DES BUNDESVERFASSUNGSGERICHTS. EINE AUSWAHL (Verein der Richter des Bundesverfassungsgerichts ed., 2004-2006).

${ }^{26}$ FILMER \& SCHWAN, supra note 10 , at 181 . In a relatively small number of instances, the Second Senate has created four screening committees instead of three; in such cases, of course, an additional number of judges must each sit on two screening committees.

${ }^{27}$ Id.; Geschäftsverteilung documents, 2000-2006 supra note 18; Geschäftsverteilung documents 1990-1999 (on file with author).

${ }^{28}$ FILMER \& SCHWAN, supra note 10, at 183. 


\section{AUthority WITH RESPECT TO THE FEDERAL JUdiCIARY}

The official title of the American Chief Justice is "Chief Justice of the United States"-not, as it is sometimes stated, "Chief Justice of the Supreme Court." Whatever this appellation may have meant in earlier periods, the American Chief Justice has assumed considerable responsibility not only for the administration of the Supreme Court, but as leader of the federal judiciary in general. Thus, the Chief Justice prepares an annual report on the state of the federal judiciary, and is often an advocate before Congress for funding and resources, not only for the Supreme Court but for all of the federal courts. Moreover, the Chief Justice is chairman of the Judicial Conference of the United States, a general governing body of the federal courts, ${ }^{29}$ and he has, or has had, other statutory authority over aspects of the federal courts. For example, the Chief Justice is authorized by statute to choosefrom among the federal judiciary-the judges who are to sit on the special courts established by the Foreign Intelligence Surveillance Act. ${ }^{30}$ Several commentators have argued that this collection of statutory authorities actually gives the Chief Justice an extended-and indeed inappropriate-degree of practical power, which may be exercised without the checks and limitations that are ordinarily present in the more traditional aspects of the judicial function. ${ }^{31}$

This sort of general judicial leadership role is largely absent in the case of the President of the German Constitutional Court. Of course, the President is the chief administrative officer of the Constitutional Court itself, and he supervises its large corps of employees. Indeed,

${ }^{29}$ The Judicial Conference was established by Congress at the urging of Chief Justice Taft, whose campaign to modernize the federal judiciary has been called his greatest accomplishment as Chief Justice. JOAN BISKUPIC \& ElDER WitT, THE SuPREME COURT AT WORK 92-93 (2d ed. 1997).

${ }^{30} 50$ U.S.C. $\$ 1803$ (2000). Under the Ethics in Government Act of 1978, a statute that is no longer in effect, the Chief Justice also had statutory authority to appoint the members of a special court (known as the Special Division), which was to supervise the work of "independent counsel" appointed under that Act. Morrison v. Olson, 487 U.S. 654, 660-61 \& n.3 (1988).

${ }^{31}$ See, e.g., Theodore W. Ruger, The Judicial Appointment Power of the Chief Justice, 7 U. PA. J. CONST. L. 341, 390 (2004) (arguing that exclusive authority vested in the Chief Justice to make appointments to the Foreign Intelligence Surveillance courts and other special courts is "problematic," because there is no way to "prevent the Chief from exercising that power in a strategic way to affect outcomes"); Judith Resnik, The Programmatic Judiciary: Lobbying, Judging, and Invalidating the Violence Against Women Act, 74 S. CAL. L. REV. 269, 285-88 (2000) (noting the "enormous influence" of the Chief Justice in selecting committees of the Judicial Conference, which may in turn determine influential recommendations of the Conference to Congress). 
this administrative authority seems to extend to rather complete control over many matters of detail: "Most policies having to do with recruitment of nonjudicial personnel, allocation of secretarial assistance and office facilities, provision and supervision of law clerks, decisions on hours and conditions of work, purchase of books and supplies, and the use of the Court's transportation pool are made by the President." ${ }^{32}$ The President also has the authority to appoint an official called the Constitutional Court Director, who reports to the President and exercises day-to-day responsibility over these administrative matters. $^{33}$

Yet, for important theoretical reasons, it is most unlikely that the President of the Constitutional Court could have any general responsibility for any of the other German courts. The reasons for this striking contrast with the role of the American Chief Justice lead us into a brief consideration of the nature of the German judiciary, as well as the origins of the German Constitutional Court.

Taking a lead from the antijudicial ideology of the French Revolution, the states of Western Europe in the nineteenth century (including Germany) developed a view of judges that seemed rather distinct from the view of common law judges that prevailed in the AngloAmerican world. The continental view emphasized the centrality of the written law-the statutes or codes-and judges were often viewed as quasi-bureaucrats who should be able to deliver syllogistic opinions derived in a logical manner from the applicable rule of law and the facts of the case. Under this view-perhaps realized more fully in France than in Germany-the judges were to reason according to very specific and narrowly defined techniques, in contrast with the (perhaps chaotic) creativity that could sometimes be expected in the common law system.

Thus, when it came to the question of establishing a Constitutional Court-first in Austria in the 1920s, and later in Germany after World War II-most experts believed that the new tribunal would be called upon to hand down quasi-political decisions that would be fundamentally different in nature from the judgments issued by the

${ }^{32}$ Kommers, JUDiCial POLITICS, supra note 4, at 91-92. On the other hand, the Court's Plenum-the joint meeting of the two Senates-retains some authority over more general administrative questions. BENDA \& KLEIN, supra note 20, at 70.

33 KOMmers, JUDiCIAL POLITICS, supra note 4, at 92, 94-95; BENDA \& KLEIN, supra note 20 , at 72 . Indeed, the Director can be a very important official within the Court, as exemplified, for example, by the career of Dr. Karl-Georg Zierlein (the Director under Roman Herzog), who was known as the Court's "gray eminence." FILMER \& SCHWAN, supra note 10, at 196-97. 
courts of the "ordinary" civil and criminal law. Moreover, it was thought that years of immersion in the technical and narrowly legal methods of the ordinary law were not likely to produce personalities who would be able, when necessary, to confront and overrule actions of the legislative or executive branches. Others thought-perhaps in contradiction with the foregoing view-that the judges of the ordinary law had been too forceful in asserting monarchist or right-wing positions against democratic governmental measures under the Weimar Republic (1919-1933). ${ }^{34}$

Therefore, following a pattern that had been developed by Hans Kelsen in Austria in the 1920s, the German Constitutional Court was basically established outside of the general legal system. Although the Constitutional Court of course must have important points of contact with the "ordinary" legal system, it is not a part of that system. ${ }^{35}$ For example, the Constitutional Court, which is basically limited to the decision of constitutional questions, has no power to set down authoritative interpretations of federal statutes or to decide any other questions of the "ordinary" law.

Thus, the Constitutional Court is a court almost exclusively for constitutional matters, which is placed outside of the system of the ordinary courts and the ordinary law-a position that contrasts substantially with that of the Supreme Court of the United States, which basically has jurisdiction not only over questions of constitutional law, but also over all other questions of federal law. In this light, it would be a sort of structural solecism for the President of the Constitutional Court-the chief officer of a court that lies outside of the general German judicial system-to be considered the head of the "ordinary" German judiciary as well.

Moreover, there is another difference in the structure of the German courts that would make such authority most unlikely if not impossible. In contrast with the United States and its extensive system of federal courts on the trial and appellate levels of adjudication, there are actually very few federal courts in Germany. Indeed, with a few minor exceptions, the only German "federal" courts are the five "supreme courts" which are placed at the top of the five separate areas

\footnotetext{
${ }^{34}$ KOMMERS, JUdiCiAl POLITICS, supra note 4, at 75.

${ }^{35}$ Rather, the system of "ordinary" law is divided up into five separate and parallel court structures, which adjudicate five separate specialized legal areas. These five areas are: (1) civil and criminal law; (2) employment law; (3) administrative law; (4) social security law; and (5) tax law. At the top of each of these five systems is a federal supreme court which controls the interpretation of law in its specific area.
} 
of "ordinary" adjudication. ${ }^{36}$ The various levels of lower courts in all of these five areas are state courts, directed by the state governments and state ministries of justice-even though they are reviewed at the top by the five federal "supreme courts," and even though most of the law that these state courts apply is federal law. That the lower courts in all five areas are state courts parallels a broader principle of the German constitutional system, which largely avoids administration of law on the federal level. Rather, the administration of federal statutes is largely undertaken by the states, and the creation of the lower courts as state courts parallels this broader bureaucratic structure.

Thus, while the President of the German Constitutional Court is the administrative chief of that court, his or her responsibility does not ordinarily extend beyond that role into the other structures of the German judiciary. It is perhaps in this characteristic that the more modest nature of the office of the President of the German Constitutional Court-in contrast with that of the American Chief Justice-is most readily apparent.

\section{INFORMAL INFLUENCE INSIDE AND OUTSIDE THE COURT}

Yet probably the most important role of the President of the German Constitutional Court-and perhaps that of the Chief Justice of the United States, as well-lies in the opportunities for informal influence both within the Court and outside of the Court. On the one hand, of course, the institution of unsigned majority opinions (as well as assignment in accordance with expertise) will deprive the President of the German Constitutional Court of the possibility of signaling particularly important decisions by virtue of his or her authorship. In this way, the President loses the representative possibilities exploited so fully by American Chief Justices, such as Chief Justice Marshall in numerous opinions for the Court, Chief Justice Warren in Brown v. Board of Education ${ }^{37}$ and Reynolds v. Sims, ${ }^{38}$ Chief Justice Burger in United States v. Nixon, ${ }^{39}$ and (to take a disastrous example) Chief Justice Taney in Dred Scott v. Sandford. ${ }^{40}$ Moreover-in part because of the practice of unsigned majority opinions, and in part because of the

\footnotetext{
${ }^{36}$ See supra note 35 . Of course, the Federal Constitutional Court itself is also a "federal" court.

37347 U.S. 483 (1954).

38377 U.S. 533 (1964).

${ }^{39} 418$ U.S. 683 (1974).

${ }^{40} 60$ U.S. (19 How.) 393 (1856).
} 
general nature of legal and social culture in Germany-the judges of the German Constitutional Court (including the President) are generally not nearly as well known in Germany as their counterparts on the Supreme Court are known in the United States.

On the other hand, as we have seen, the institution of unsigned majority opinions may yield pressures within the Court that give the President particular scope (within one Senate, at least) for the exercise of mediating powers, if he or she has-as President HöpkerAschoff apparently had-a "genius" in the skills of mediation.

From time to time in the history of the Constitutional Court, moreover, the President of the Court has played an important representative role in public controversies concerning the Court, and in struggles with other political forces. In certain of these instances, the representative role of the Court's President seems to have, if anything, exceeded similar activities by the Chief Justice of the United States. Let us focus on two important examples of this phenomenon.

In the early 1950s-almost at the outset of its existence-the Constitutional Court was engaged in a political struggle with the Adenauer government over issues having to do with the constitutionality of a proposed plan for integrating European military forces. At the same time, the Court was embroiled with the Federal Justice Ministry over the hotly contested question of whether the Constitutional Court should be treated as a separate "constitutional organ"-on the level of the federal government, the federal parliament, and the federal President—or whether, on the contrary, it should be administratively treated as just another court, subject to the budgetary and other supervision of the Ministry of Justice. ${ }^{41}$

In these disputes, the Court's first President, Hermann HöpkerAschoff, played a significant role through public debate and internal governmental pressure. Indeed, President Höpker-Aschoff informed Chancellor Adenauer and Federal President Heuss that he would resign if a particularly hostile Justice Minster, who had bitterly attacked the Court, were reappointed to the cabinet-and the Justice Minister was not reappointed. In the end, the Court "very adroitly survived the

\footnotetext{
${ }^{41}$ For discussion of these controversies, see WESEL, supra note 4, at 54-82; KOMMERS, JUDICIAL POLITICS, supra note 4, at 83-86, 282-86. The theoretical underpinnings of the Court's position on the question of its status rested on a memorandum written principally by the eminent law professor and Constitutional Court judge, Gerhard Leibholz. WESEL, supra note 4, at 78-79; see also Gerhard Leibholz, Der Status des Bundesverfassungsgerichts, in DAS BUNDESVERFASSUNGSGERICHT: 1951-1971, at 31-57 (1971) (setting forth Leibholz's views on the status question).
} 
crisis [over the European military force] and solidified its esteem among the public" through the independence of its judgments. ${ }^{42}$ In that crisis, "the judges stood solidly together with their President [Höpker-Aschoff] who represented, with great dignity, the independence of the Court." ${ }^{43}$

Another extraordinary effort of a Constitutional Court President in seeking to protect the Court as an institution-on this occasion, against widespread public attack, rather than against internal government maneuvering-was strikingly evident during the recent tenure of Constitutional Court President Jutta Limbach. In 1994 and 1995, almost at the outset of Limbach's term of office, the Court handed down a number of decisions that infuriated important conservative groups in Germany. For example, the Court found that many East German spies were immune from prosecution in unified Germany; ${ }^{44}$ that public references to soldiers as "murderers" often constituted protected speech; ${ }^{45}$ that antimissile sit-down protestors could not be constitutionally punished under a statute whose language had been drastically extended to achieve that end; ${ }^{46}$ and that crucifixes could not constitutionally be placed in public school classrooms over the objection of parents or students. ${ }^{47}$ Although some of these results might have seemed unexceptionable in American constitutional law, they were surprising to many German citizens. In any case, perhaps as a result of the strong protection of minority interests reflected in these cases, and perhaps because of the Court's apparent devaluation of traditional German institutions such as the army and the church, these decisions evoked an unprecedented public attack on the institu-

${ }^{42}$ WESEL, supra note 4 , at 74-75.

${ }^{43} I d$. at 75 . This effective defense of the independence of the Constitutional Court within the councils of government may be comparable to the letter written by Chief Justice Hughes to an influential senator for the purpose of combating President Roosevelt's Court-packing plan by denying the necessity of additional Justices. ROBERT J. SteAmer, Chief Justice: LeAdership AND the Supreme COURT 58-59 (1986). At a considerably earlier period, Chief Justice Marshall sent a letter to House Speaker Henry Clay, which had a similar purpose and a similar result. Hobson, supra note 22, at 1457 .

${ }^{44}$ Bundesverfassungsgericht [BVerfG] [Federal Constitutional Court] May 15, 1995, 92 Entscheidungen des Bundesverfassungsgerichts [BVerfGE] 277 (F.R.G.).

${ }^{45}$ BVerfG, Oct. 10, 1995, 93 BVerfGE 266.

${ }^{46}$ BVerfG, Jan. 10, 1995, 92 BVerfGE 1.

${ }^{47}$ BVerfG, May 16, 1995, 93 BVerfGE 1. 
tion of the Constitutional Court. Indeed, according to some, this was the "greatest crisis" of the Court's history. ${ }^{48}$

In response to this wave of criticism, President Limbach launched into a vigorous round of discussions and interviews with important national journals such as the Spiegel magazine, as well as other representatives of the German media. In these discussions, Limbach sought to elucidate the nuanced nature of the controversial decisions which, in her view, were not as extreme as the critics had maintained. More generally, she sought to explain the importance of the independence of the judiciary in a liberal republic. The fact that most of the controversial decisions had been issued by the First Senate-the Senate on which President Limbach did not sit—may have made her defense of the Court even more persuasive.

After a year or so, the crisis passed, and the Court reassumed its position of highest esteem among the political organs of the Federal Republic. Many commentators credited President Limbach, in significant part, for this result. ${ }^{49}$ But even thereafter, President Limbach continued to maintain a heavy schedule of discussions and television appearances on issues relating to the Constitutional Court. Overall, in her defense and representation of the Court, President Limbach displayed a willingness to engage in extrajudicial discussion and explanation that went considerably beyond anything of the sort that has been seen in a Chief Justice of the United States-in recent times at least. ${ }^{50}$

\section{CONCLUSION}

A comparison of relevant aspects of the German and American constitutional tribunals shows that differences in the structures of the

\footnotetext{
${ }^{48}$ DECKENBACH, supra note 12, at 181. For a detailed discussion of these cases and the Constitutional Court crisis of 1995, see Peter E. Quint, The Pershing Missile Protests: Civil Disobedience and the German Constitutional Court, ch. V (unpublished manuscript, on file with author). For President Limbach's reflections on the crisis, see JUtTA LimbaCh, "IM NAMEN DES VOLKeS": MACHT UND VERANTWORTUNG DER Richter 165-201 (1999).

${ }^{49}$ DECKENBACH, supra note 12, at 192 . For the purpose of creating a more permanent institution, Limbach established the Court's Press Office (Pressestelle), which would have the task, among others, of preparing explanatory press releases for constitutional decisions. Id. at 186-87.

${ }^{50} I d$. at 181-86, 194, 207-08. In what may have been a unique effort-unparalleled in Germany as in the United States-Chief Justice Marshall wrote an anonymous defense of McCulloch $v$. Maryland, which was published in a Virginia newspaper and sent to influential political figures in Virginia. Hobson, supra note 22, at 1446; JOHN MARSHALL'S DEFENSE OF MCCULLOCH V. MARYLAND (Gerald Gunther ed., 1969).
} 
two courts yield differences in the comparative power and authority of the chief judicial officers of those courts-the Chief Justice of the United States and the President of the German Constitutional Court.

For the most part, relevant structural characteristics of the German Constitutional Court seem to limit the authority of the President's role in comparison with that of the American Chief Justice. For example, the division of the Constitutional Court into two separate Senates (in comparison with the "one Supreme Court") decreases the influence of the President over certain internal functions of the Court. Moreover, the limitation of the German justices' terms of office to a maximum of twelve years significantly curtails the President's opportunity for long-term exercise of influence, in comparison with the opportunities open to the American Chief Justice with his lifetime tenure. In addition, the President's quite limited control over the assignment of the Court's opinions (and the unsigned nature of those opinions) greatly reduces a source of influence that is possessed by the American Chief Justice-although a President with skills as a mediator may still exercise some special influence within his or her own Senate. Finally, the President of the Constitutional Court is not placed at the head of an extended federal judiciary, in contrast with the role of the Chief Justice of the United States; accordingly, the possibly questionable accumulation of power that some commentators have seen in this aspect of the Chief Justice's role does not seem to be present in Germany.

On the other hand, the President of the German Constitutional Court may gain some advantage by ordinarily being placed on two of the Court's screening committees (whereas other justices ordinarily sit on only one committee), but this advantage may be counterbalanced by the President's diminished opportunity to be the primary drafter (Reporter) of the Court's majority opinions.

Yet a significant part of this deficit may be made up by the President's representative role- a role also played by the Chief Justice of the United States. Indeed, in certain instances, the President has played an important political role-either warding off incursions from other parts of the government, or making use of broad access to publicity in television and national journals to defend against public attacks on the Court and to further the Court's acceptance among the public. On significant occasions, the President has exercised this role 
with a vigor that seems to have gone rather significantly beyond any representative functions of this type that have been exercised, in recent decades at least, by the Chief Justice of the United States. 


\section{APPENDIX \\ THE EIGHT PRESIDENTS OF THE GERMAN \\ CONSTITUTIONAL COURT (1951-2006)}

1. Hermann Höpker-Aschoff, President 1951-1954. Höpker-Aschoff, the first President of the German Constitutional Court, had been an eminent Prussian finance minister and a Member of Parliament under the Weimar Republic. ${ }^{51}$ After World War II, he became an important member of the Parliamentary Council, which drafted the German Basic Law, and, in accordance with his fiscal experience, he was active in work on the financial provisions of the constitution. ${ }^{52}$ Thereafter, he became a leader of the Free Democratic Party (FDP), which joined the center-right coalition government under Chancellor Adenauer. ${ }^{53}$

In his work as President of the Court, Höpker-Aschoff may not have been an eminent legal technician, but he was regarded as a "genius" in achieving unanimity among the justices. ${ }^{54}$ Moreover, as a matter of style, he was less interested in "the niceties of constitutional interpretation" than in "a decision that was supported by common

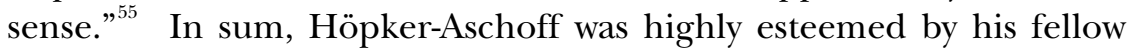
judges, and he was a strong leader who protected the Court against political attack. ${ }^{56}$

2. Josef Wintrich, President 1954-1958. Before coming to the Court, Wintrich had been a professor and judge in Munich, and he had played a central role in the development of the Constitutional Court of Bavaria, the first state constitutional court to be created in Germany after World War II. ${ }^{57}$ Wintrich was a "scholarly ... man of culture and refinement, [and] one of Germany's most respected ju-

${ }^{51}$ G.W., Der Präsident des Bundesverfassungsgerichts, 7 NEUE JURISTISCHE WOCHENSCHRIFT [NJW] 544, 545 (1954).

${ }^{52}$ Id:; Edmund SPEvack, Allied Control AND German Freedom 295, 376 (2001); KomMERS, JUdiCiAL POLITICS, supra note 4, at 124.

${ }_{53}$ KOMMERS, JUdiCiAL POLITICS, supra note 4, at 123-24.

${ }^{54} I d$. at 189.

${ }^{55}$ Konrad Zweigert, Duktus der Rechtsprechung des ersten Senats des Bundesverfassungsgerichts und einige Erinnerungen an seine Anfangszeit, in DAS BUNDESVERFASSUNGSGERICHT, supra note 41, at 95, 116.

${ }^{56}$ KOMMERS, JUdiCIAL POLITICS, supra note 4, at 124, 189; WeSEL, supra note 4, at 54-82; see also Theodor Ritterspach, Erinnerungen an die Anfänge des Bundesverfassungsgerichts, in GRUNDRECHTE, SOZIALE ORDNUNG UND VERFASSUNGSGERICHTSBARKEIT: FESTSCHRIFT FÜR ERNST BENDA ZUM 70. GEBURTSTAG 201, 203 (Eckart Klein ed., 1995) (noting the exemplary qualities of Höpker-Aschoff as President).

57 Alfons Goppel, Zum Gedenken an Josef Wintrich, 14 JURISTENZEITUNG [JZ] 186, 187 (1959); G.W., supra note 51, at 544. 
rists." ${ }^{58}$ But he seems to have been a rather ineffectual Constitutional Court President. It has been said, for example, that he "had a Hamletlike tendency toward indecision" in the Communist Party dissolution case, which was probably the most important case considered during his tenure. ${ }^{59}$ Indeed, Wintrich apparently approached Chancellor Adenauer and urged him to withdraw the government's complaint against the Communist Party-a step that Adenauer refused to take. ${ }^{60}$

As a scholar, Wintrich was a prominent exponent of the view that certain constitutional principles were so fundamental that they could not even be altered by constitutional amendment-a view that contrasted sharply with the prevailing German positivism of earlier eras. ${ }^{61}$ Wintrich died after serving only four and a half years of his tenure as Constitutional Court President.

3. Gebhard Müller, President 1959-1971. In the early years of his legal career, Gebhard Müller was a trial court judge (Amtsrichter) during the Weimar Republic and under the Nazis, and he became an official in the judicial bureaucracy at the outset of the occupation period. $^{62}$ Soon after the war ended, however, he turned his attention to politics, and he held a number of important positions in state government and in the newly formed political party, the Christian Democratic Union (CDU). In 1953, Müller became Minister-President (governor) of the southwestern German State of Baden-Württemberg, which had recently been created from three separate states of the occupation period. ${ }^{63}$ After five years as governor during a politically difficult period, Müller accepted his appointment as President of the Constitutional Court, apparently with a sense of relief. ${ }^{64}$

45 .

${ }^{58}$ KOMmers, JUdiCial POLITICS, supra note 4, at 133; G.W., supra note 51, at 544-

${ }^{59}$ KOMMERS, JUdiCIAL POLITICS, supra note 4, at 134.

${ }^{60} I d$. at 190-91; WESEL, supra note 4, at 90-91.

${ }^{61}$ Goppel, supra note 57, at 187-88; cf. Josef Wintrich, Rechtsidee und Verfassungsrichtertum, 9 JZ 454, 455 (1954) (reprinting Wintrich's speech upon induction as Constitutional Court President, which argued that the Basic Law adopted "dignity of the person" and "equality before the law" as "principles of constitutional law ... with absolute validity").

${ }^{62}$ Kurt Hochstuhl, Lebensziel Amtsrichter? Anmerkungen zur Biographie Gebhard Müllers bis 1945, in GEBHARD MÜLLER: EIN LEBEN FÜR DAS RECHT UND DIE POLITIK 9, 12-17 (Gerhard Taddey ed., 2000).

${ }^{63}$ Klaus-Jürgen Matz, Gebhard Müller als erster Oppositionsführer und zweiter Ministerpräsident im neuen Südweststaat 1952-1958, in GEBHARD MÜLLER: EIN LEBEN FÜR DAS RECHT UND DIE POLITIK, supra note 62, at 61, 62.

${ }^{64} I d$. at $62-63,70$. 
As President of the Constitutional Court, Müller was an excellent administrator, and he worked diligently to reduce the Court's backlog of cases. ${ }^{65}$ During his period on the Court, Müller took some decidedly conservative positions, both with respect to the Court as an institution and also on points of doctrine. He resisted, for example, the introduction of dissenting opinions in $1970,{ }^{66}$ and it appears that he generally favored interests of "community norms and moral values" over those of freedom of speech, while he criticized particular types of social security as unduly statist. ${ }^{67}$ After his retirement, Müller was appointed Honorary Professor at the University of Tübingen. ${ }^{68}$

4. Ernst Benda, President 1971-1983. A member of parliament's influential judiciary committee, Benda was regarded as the preeminent legal theorist in the CDU; he first came to prominence with a stirring parliamentary speech warning that a statute of limitations threatened to put an end to prosecutions of Nazi atrocities-a speech that did not necessarily please the leaders of his conservative party. ${ }^{69}$

As Federal Interior Minister (1968-1969) in the so-called "Grand Coalition," Benda was the chief architect of the emergency laws of 1968, which many feared heralded a return to possible authoritarianism in Germany. ${ }^{70}$ Yet on the Constitutional Court, Benda also espoused more libertarian positions; he was a key supporter, for example, of an important Constitutional Court decision that struck down an intrusive census law as a violation of rights of privacy. ${ }^{71}$ In sum, he was "too far right for those on the left, but too far left for many on the right." " As the first President in office after separate opinions of the justices were introduced, Benda made use of this possibility only once in his career. ${ }^{73}$

${ }^{65}$ Walter Rudi Wand, Gebhard Müller 80 Jahre, 35 JZ 280, 281 (1980); Helmut Engler, Der Präsident des Bundesverfassungsgerichts 1959-1972, in GEBHARD MÜLLER: EIN LEBEN FÜR DAS RECHT UND DIE POLITIK, supra note 62, at 71, 77.

${ }^{66}$ Engler, supra note 65, at 76-77; KOMMERS, JUdiCIAL POLITICS, supra note 4, at 194; supra note 17 and accompanying text.

${ }^{67}$ Kommers, JUdicial POLITICS, supra note 4, at 153-54.

${ }^{68}$ Wand, supra note 65, at 281.

${ }^{69}$ Kommers, Judicial Politics, supra note 4, at 143; Helmut Simon, Ernst Benda zum 70. Geburtstag, 120 ARCHIV DES ÖFFENTLICHEN RECHTS 138, 138 (1995).

${ }^{70}$ See generally ERNST BENDA, DER RECHTSSTAAT IN DER KRISE 76-107 (1972) (setting forth Benda's defense of the emergency laws).

${ }^{71}$ WESEL, supra note 4, at 216.

${ }^{72}$ Simon, supra note 69, at 139 (quoting R. Reifenrath).

${ }^{73}$ Konrad Hesse, Skepsis und Zuversicht, in Klein, supra note 56, at 1, 5. 
After his twelve-year Court term expired at the relatively early age of fifty-eight, Benda became a professor of public law at the University of Freiburg. ${ }^{74}$ Always deeply interested in American law, Benda included this comparative topic prominently in his seminars in Freiburg, and he spent time in the United States as a Fellow at the Woodrow Wilson International Center for Scholars in Washington. ${ }^{75}$

5. Wolfgang Zeidler, Vice President 1975-1983; President 1983-1987. A founder of the student branch of the Social Democratic Party (SPD), Wolfgang Zeidler served as a law clerk at the Constitutional Court and then became a judge in the civil and administrative courts; he was also active in the administration of the government of Hamburg. ${ }^{76}$ Zeidler was first elected a justice of the Constitutional Court in 1967, but he left in 1970 to take up the post of President of the Federal Administrative Court, one of the five "supreme courts" of the general judiciary. In 1975 he was reelected to the Constitutional Court as Vice President, and he became President in 1983.

Although Zeidler was elected to the Court as a candidate of the SPD-and, indeed, was the first Social Democrat to be chosen President of the Court-he often voted with the conservative side in important political cases throughout his career as President. ${ }^{77}$ Zeidler strove for compromise and issued only one separate opinion (a concurrence) in his years on the Court. ${ }^{78}$

Early in his career, Zeidler had spent a year as Research Fellow at the Harvard Law School, and he was noted for his internationalism and his interest in Anglo-American law. Zeidler died in a mountaineering accident in 1987.

6. Roman Herzog, Vice President 1983-1987; President 1987-1994. At the outset of his career, Roman Herzog was a law professor in Berlin and Speyer and the coauthor of a well-known multi-volume commentary on the German Constitution. He then entered political life, ascending to the office of Interior Minister in the State of BadenWürttemberg, from which he was elected to the Constitutional Court.

Although Herzog had taken a very hard line against anti-nuclear demonstrators as Interior Minister in Baden-Württemberg, as a Con-

\footnotetext{
${ }^{74}$ MenZel, supra note 8, at 665.

${ }^{75}$ Hesse, supra note 73, at 2, 9.

${ }^{76}$ Most of the biographical material in this section is drawn from Walther Fürst et al., Geleitwort, in FESTSCHRIFT FÜR WOLFGANG ZEIDLER xv, xv-xix (Walther Fürst et al. eds., 1987).

${ }^{77}$ WESEL, supra note 4 , at 215-16.

${ }^{78}$ Fürst et al., supra note 76 , at xvi.
} 
stitutional Court judge he was an important supporter of the Court's Brokdorf opinion, which established broad protections for demonstrations under the Basic Law. ${ }^{79}$ Herzog presided over a number of important cases arising from German unification, including a controversial decision upholding a rule excluding large tracts of land expropriated by the Soviet occupation regime from a general program of returning confiscated property. ${ }^{80}$ As a matter of style, President Herzog took particular care to achieve strong majority votes, and he never issued a dissenting or concurring opinion in his years on the Constitutional Court. ${ }^{81}$

Herzog's term on the Court was cut short by his election, in 1994, to the office of President of the Federal Republic of Germany.

7. Jutta Limbach, President 1994-2002. In a career path similar to that of Roman Herzog, Jutta Limbach was a law professor who entered government and was thereafter elected to the Constitutional Court. ${ }^{82}$ A long-time professor of law and the sociology of law at the Free University of Berlin, Limbach became Attorney General (Justizsenator) in the state government of West Berlin, shortly before German unification. As Attorney General, she showed notable vigor in the prosecution of East German officials (including former East German dictator Erich Honecker) for actions such as the use of deadly force against people attempting to flee across the Berlin Wall. She also acted to prevent East Berlin judges, who may have been implicated in the injustices of the old regime, from continuing in office without a stringent review and evaluation of their records. Her role as Attorney General in Berlin made her well known throughout the Federal Republic.

On the Court, Judge Limbach dissented in a significant decision on the rights of political asylum, and she and other judges dissented from the prevailing view in an important case on the deployment of German forces under the NATO Treaty. But her tenure was particularly notable for her vigorous public defense of the Constitutional Court in unprecedented controversies over unpopular Court decisions, and her defense of the Court is said to have been important in

\footnotetext{
${ }^{79}$ WESEL, supra note 4, at 216, 217; see also FILMER \& SCHWAN, supra note 10 , at 184-85.

${ }^{80}$ See FILMER \& SCHWAN, supra note 10, at 187-88.

${ }^{81} I d$. at 194-95. This means, of course, that Herzog never issued a signed opinion during his tenure on the Court.

${ }^{82}$ Most of the biographical material in this section is drawn from DECKENBACH, supra note 12.
} 
protecting the institution from serious political damage. ${ }^{83}$ Limbach also established the Press Office of the Constitutional Court in an attempt to promote greater understanding of the Court's work among the German public.

8. Hans-Jürgen Papier, Vice President 1998-2002; President 2002present. Hans-Jürgen Papier began his legal career as a professor of public law in Bielefeld and Munich. After German unification, he was appointed to lead a government commission which investigated the origins of property held by the Communist Party of East Germany and made influential recommendations for its disposition. Papier was elected to the Constitutional Court as Vice President in 1998 and became President upon the retirement of Jutta Limbach in $2002 .{ }^{84}$

${ }^{83}$ Id. at 192.

${ }^{84}$ Menzel, supra note 8, at 670; Résumé of Hans-Jürgen Papier, http:// www.bverfg.de/richter/papier.html (last visited Apr. 20, 2006). 